\title{
HUBUNGAN TINGKAT PENGETAHUAN DENGAN TINDAKAN PERAWAT DALAM PENGELOLAAN SAMPAH MEDIS DI RSU SEMBIRING DELI TUA TAHUN 2018
}

\author{
Bungamari Sembiring, M. Kes ${ }^{1}$, Fithri Handayani Lubis, M. Kes² \\ Institut Kesehatan Deli Husada Deli Tua \\ Jl. Besar No. 77 Deli Tua Kab. Deli Serdang - Sumatera Utara 20355 \\ Fakultas Kesehatan Masyarakat \\ Email : @bungasembiring715@gmail.com \\ DOI : https://doi.org/10.35451/jkg.v1i2.171
}

\begin{abstract}
The hospital is one of health service units that produces medical waste. Medical waste management well be giving effect to health workers, patients and the patient's family. Toable do medical waste management is needed good knowledge and behavior of nurses. The results of pre study at Sembiring hospital, there are activity of nurses of medical waste management like a needle, spuit, a bandage thrown away without separated. Thepurposes of this study is to know The Relationship The Level Of Knowledge With The Actions Nurse Of Medical Waste Management In Sembiring Hospital Deli tua City. The design of study is qualitative and quantitative. The method use descriptive correlative, with cross sectional approach. The populatin study are all of nurses count 50 persons. The sample wew 44 respondents, taken a sample of 44 respondents with a simple random sampling technique. The instrument study used knowledge questionnaire and questionnaire actions of medical waste management after validity and reability tested. The data then tested with Chi Square test. The result showed that 5 respondents $(55,6 \%)$ with knowledge isn't good doesn't take action and 4 respondents (44,4\%) with that takes action of medical waste management. The result of rank the Chi Square test obtained $p$ value $=0,010 ; a=0,05$. The conclusion of the study there were relationship the level of knowledge with the actions nurse of medical waste management in Sembiring hospital. The higher the nurse's knowledge about medical waste management, the better the nurse's actions in managing medical waste.
\end{abstract}

Keyword : Knowledge, Action, Medical Waste Management, Nurse 


\section{PENDAHULUAN}

Limbah rumah sakit adalah semua limbah baik yang berbentuk padat maupun cair yang berasal dari kegiatan rumah sakit baik kegiatan medis maupun nonmedis yang kemungkinan besar mengandung mikroorganisme, bahkan kimia beracun, dan radioaktif. Apabila tidak ditangani dengan baik, limbah rumah sakit dapat menimbulkan masalah baik dari aspek pelayanan maupun estetika selain dapat menyebabkan pencemaran lingkungan dan menjadi sumber penularan penyakit (infeksi nosokomial). Oleh karena itu, pengelolaan limbah rumah sakit perlu mendapat perhatian yang serius dan memadai agar dampak negatif yang terjadi dapat dihindari atau dikurangi (Chandra, 2018).

\section{World Health Organization}

(WHO, 2010) melaporkan limbah yang dihasilkan layanan kesehatan (rumah sakit) hampir $80 \%$ berupa limbah umum dan $20 \%$ berupa limbah bahan berbahaya yang mungkin menular, beracun atau radioaktif. Sebesar $15 \%$ dari limbah yang dihasilkan layanan kesehatan merupakan limbah infeksius atau limbah jaringan tubuh, limbah benda tajam sebesar $1 \%$ limbah kimia dan farmasi $3 \%$ dan limbah genotoksik dan radioaktif sebesar $1 \%$ (Jurnal Nurharyanti, 2016).

Rumah sakit menghasilkan limbah dalam jumlah besar, beberapa diantaranya membahayakan kesehatan lingkungannya. Dalam upaya meningkatkan derajat kesehatan masyarakat, khususnya di kota-kota besar semakin meningkat pendirian rumah sakit (RS). Sebagai akibat limbah rumah sakit tidak memenuhi syarat. Limbah rumah sakit dapat mencemari lingkungan penduduk di sekitar rumah sakit dan dapat menimbulkan masalah kesehatan. Hal ini dikarenakan dalam limbah rumah sakit dapat mengandung berbagai jasad renik penyebab penyakit pada manusia termasuk demam typhoid, kholera, disentri, dan hepatitis sehingga limbah harus diolah sebelum di buang ke lingkungan (Asmadi, 2013).

Pengelolaan sampah atau limbah medis semestinya memiliki izin dari Kementerian Lingkungan Hidup. Jika sampah medis tercecer, yang berasal dari kimiawi, limbah farmasi, darah dan perban, dan dimanfaatkan oleh orangorang yang tidak bertanggung jawab, ini bisa berdampak pada penyakit-penyakit yang membahayakan masyarakat. Bila ada rumah sakit yang melanggar standar pembuangan limbah dan pengelolaannya, Kementerian Kesehatan atau kementerian Lingkungan hidup bisa menindak tegas pengelola rumah sakit, limbah medis berbeda dengan limbah umum atau rumah tangga. Sebab limbah medis yang tidak dikelola dengan baik, dapat menimbulkan penyakit (Sumutpos, 2017).

\section{METODE PENELITIAN}

Jenis penelitian yang digunakan adalah penelitian kuantitatifdankualitatif. Metode yang digunakan adalah survey observasi, dengan pendekata cross sectional ialah suatu penelitian untuk mempelajari korelasi antara hubungan tingkat pengetahuan dengan tindakan perawat dalam pengelolaan sampah medis di RSU Sembiring Deli tua Tahun 2018. Teknik pengambilan sampel pada penelitian ini menggunakan teknik Random Sampling yaitu pengambilan sampel secara random atau acak dengan teknik pengambilan sampel secara acak sederhana (Simple Random Sampling). Populasi yang terdapat dalam penelitian ini berjumlah 50 orang perawat dengan tingkat signifikansi 0,05 (5\%), dengan menggunakan rumus Slovin sehingga dihasilkan 44 responden dari jumlah 50 responden. 


\section{HASIL PENELITIAN}

\section{a. Hasil Univariat}

Tabel 3.1 Distribusi Frekuensi Karakteristik Responden Berdasarkan Umur di RSU Sembiring Deli tua

\begin{tabular}{|c|c|c|c|}
\hline No. & Umur & Jumlah & $\begin{array}{c}\text { Persentase } \\
(\%)\end{array}$ \\
\hline 1. & $\begin{array}{l}20-29 \\
\text { Tahun }\end{array}$ & 34 & 77,3 \\
\hline 2. & $\begin{array}{c}30- \\
39 \\
\text { Tahun }\end{array}$ & 8 & 18,2 \\
\hline \multirow[t]{2}{*}{3.} & $\begin{array}{l}>40 \\
\text { Tahun }\end{array}$ & 2 & 4,5 \\
\hline & Total & 44 & 100 \\
\hline \multicolumn{4}{|c|}{$\begin{array}{l}\text { Analisa Data : Tabel di atas } \\
\text { menunjukkan bahwa presentasi umur } \\
\text { responden yang terbesar adalah } \\
\text { kelompok umur } 20-29 \text { tahun sebanyak } \\
34 \text { orang }(77,3 \%) \text {,kelompok umur } 30- \\
39 \text { tahun sebanyak } 8 \text { orang }(18,2 \%) \text {, } \\
\text { dan yang paling sedikit pada kelompok } \\
\text { umur }>40 \text { Tahun sebanyak } 2 \text { orang } \\
(4,6 \%) \text {. }\end{array}$} \\
\hline
\end{tabular}

Tabel 3.2 Distribusi Frekuensi Karakteristik Responden Berdasarkan Jenis Kelamin di RSU Sembiring Deli tua

\begin{tabular}{|c|c|c|c|}
\hline $\begin{array}{c}\text { No } \\
\text {. }\end{array}$ & $\begin{array}{c}\text { Jenis } \\
\text { Kelamin }\end{array}$ & $\begin{array}{c}\text { Jumla } \\
\text { h }\end{array}$ & $\begin{array}{c}\text { Persenta } \\
\text { se }(\%)\end{array}$ \\
\hline 1. & Laki-Laki & 15 & 34,1 \\
\hline 2. & $\begin{array}{c}\text { Perempu } \\
\text { an }\end{array}$ & 29 & 65,9 \\
\hline & Total & 44 & 100 \\
\hline
\end{tabular}
menunjukkan bahwa presentasi jenis kelamin responden mayoritas berjenis kelamin perempuan sebanyak 29 orang $(65,9 \%)$ dan berjenis kelamin laki-laki sebanyak 15 orang $(34,1 \%)$.
Tabel 3.3 Distribusi Frekuensi Karakteristik Responden Berdasarkan Pendidikan di RSU Sembiring Deli tua

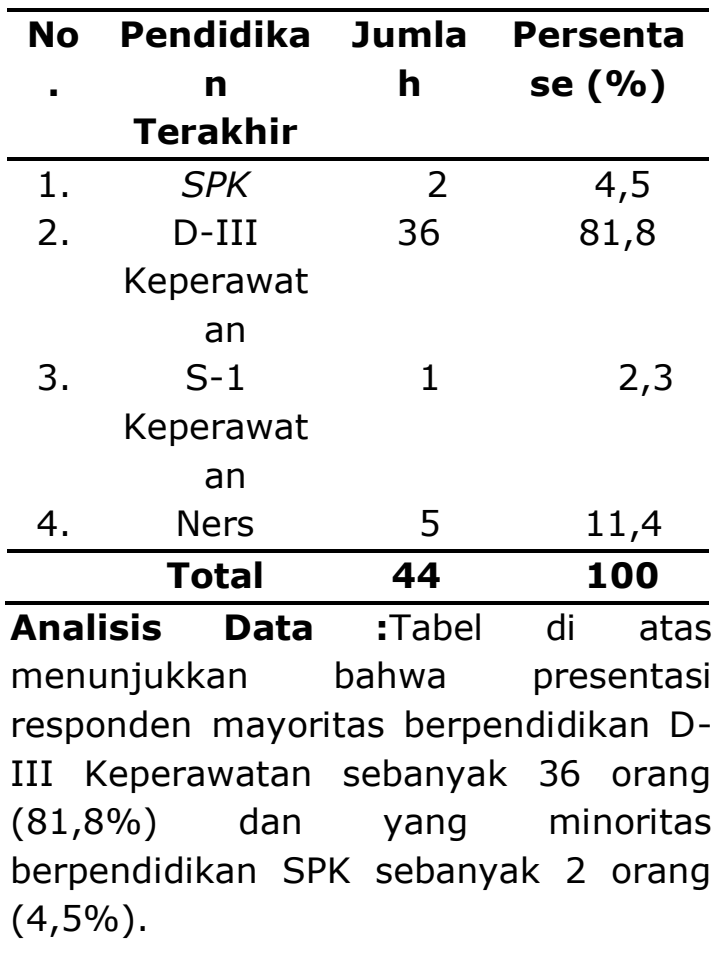

Tabel 3.4 Distribusi Frekuensi Karakteristik Responden Berdasarkan Lama Bekerja di RSU Sembiring Deli tua

\begin{tabular}{cccc}
\hline No. & $\begin{array}{c}\text { Lama } \\
\text { Kerja }\end{array}$ & Jumlah & $\begin{array}{c}\text { Persentase } \\
(\mathbf{\%})\end{array}$ \\
\hline 1. & $0-9$ & 42 & 95,5 \\
Tahun & & \\
2. $\begin{array}{c}>10 \\
\text { Tahun }\end{array}$ & 2 & 4,5 \\
\hline & Total & $\mathbf{4 4}$ & $\mathbf{1 0 0}$ \\
\hline
\end{tabular}

Analisis Data : Tabel di atas menunjukkan bahwa responden yang bekerja mayoritas selama bekerja 0-9 tahun sebanyak 42 orang $(95,5 \%)$, dan yang bekerja selama $>10$ tahun sebanyak 2 orang $(4,5 \%)$.

\section{Pengetahuan Responden \\ Berdasarkan hasil penelitian pengetahuan responden diperoleh}


pengetahuan responden terhadap pengelolaan sampah medis di RSU Sembiring Deli tua sebagai berikut :

Tabel 3.5 Distribusi Frekuensi Berdasarkan Pengetahuan Respondendi RSU Sembiring Deli tua Tahun 2018

\begin{tabular}{cccc}
\hline $\begin{array}{c}\text { No } \\
.\end{array}$ & $\begin{array}{c}\text { Pengetah } \\
\text { uan }\end{array}$ & $\begin{array}{c}\text { Juml } \\
\text { ah }\end{array}$ & $\begin{array}{c}\text { Persenta } \\
\text { se } \mathbf{( \% )}\end{array}$ \\
\hline 1. & Baik & 35 & 79,5 \\
2. & Tidak Baik & 9 & 20,5 \\
\hline & Total & $\mathbf{4 4}$ & $\mathbf{1 0 0}$ \\
\hline
\end{tabular}

Analisis Data : Berdasarkan tabel di atas diperoleh bahwa mayoritas pengetahuan responden adalah pengetahuan yang baik sebanyak 35 orang $(79,5 \%)$ dan pengetahuan tidak baik sebanyak 9 orang $(20,5 \%)$.

\section{Tindakan Responden Dalam Pengelolaan Sampah Medis}

Berdasarkan hasil penelitian tindakan responden diperoleh tindakan responden terhadap pengelolaan sampah medis di RSU Sembiring Deli tua sebagai berikut :

Tabel 3.6 Distribusi Frekuensi Berdasarkan Tindakan Responden Dalam Pengeloaan Sampah Medis di RSU Sembiring Deli tua Tahun 2018

\begin{tabular}{cccc}
\hline No & $\begin{array}{c}\text { Tindaka } \\
\text {. }\end{array}$ & $\begin{array}{c}\text { Jumla } \\
\mathbf{h}\end{array}$ & $\begin{array}{c}\text { Persentas } \\
\mathbf{e}(\mathbf{\%})\end{array}$ \\
\hline 1. & $\begin{array}{c}\text { Melakuka } \\
\mathrm{n}\end{array}$ & 35 & 79,5 \\
2. & $\begin{array}{c}\mathrm{n} \text { Tidak } \\
\text { Melakuka } \\
\mathrm{n}\end{array}$ & 9 & 20,5 \\
& & \\
\hline & Total & $\mathbf{4 4}$ & $\mathbf{1 0 0}$
\end{tabular}

Analisis Data : Berdasarkan tabel di atas diperoleh bahwa mayoritas tindakan responden dalam pengelolaan sampah medis adalah melakukan tindakan sebanyak 35 orang $(79,5 \%)$ dan tidak melakukan tindakan sebanyak 9 orang $(20,5 \%)$.

\section{b. Hasil Bivariat}

Analisis bivariat bertujuan untuk mengetahui hubungan variabel independen (pengetahuan) terhadap variabel dependen (tindakan dalam pengelolaan sampah medis) dengan menggunakan analisis uji chi square.Melalui uji statistik chi square akan di peroleh nilai $p$, dimana dalam penelitian ini digunakan tingkat keamanan sebesar 0,05. Penelitian antara dua variabel dikatakan bermakna jika mempunyai nilai $\mathrm{p}<0,05$ yang berarti Ho ditolak dan Ha diterima, dan dikatakan tidak bermakna jika mempunyai nilai $p>0,05$ yang berarti $\mathrm{Ho}$ diterima dan $\mathrm{Ha}$ ditolak. Selanjutnya hasil analisis bivariat akan dijelaskan pada tabel dibawah ini :

Tabel 3.7 Tabel Silang Hubungan Tingkat pengetahuan Dengan Tindakan Perawat Dalam Pengelolaan Sampah Medis Di RSU Sembiring Deli tua Tahun 2018

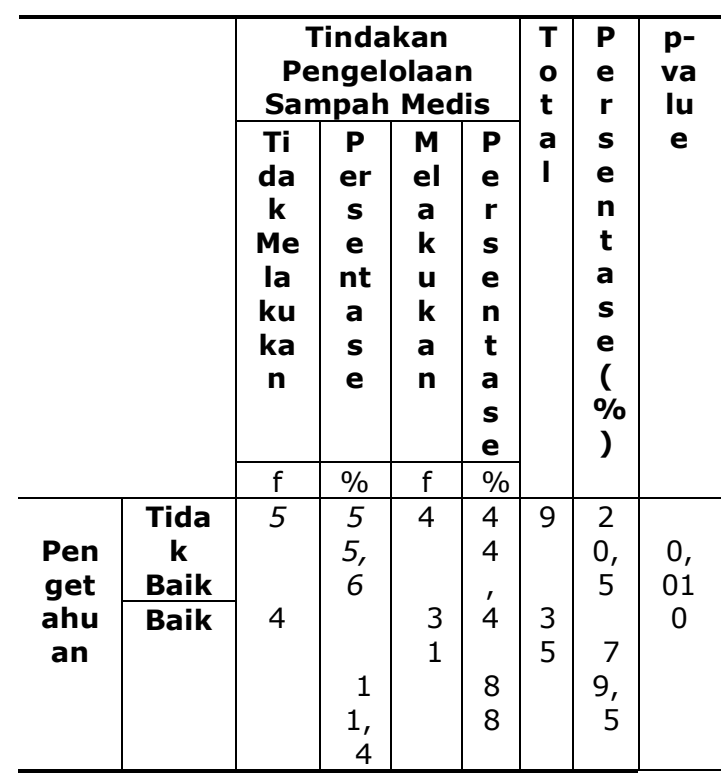




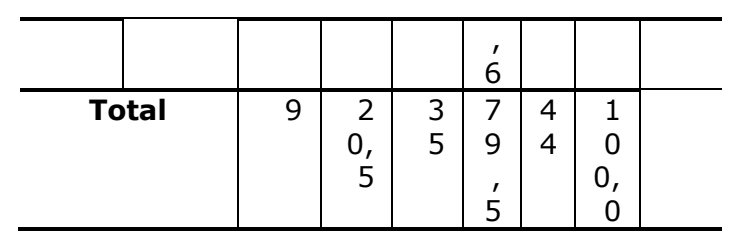

Berdasarkan tabel 4.7 didapat hasil responden paling banyak dengan kategori pengetahuan tidak baik dan tidak melakukan tindakan sebanyak 5 orang $(55,6 \%)$, dan responden yang pengetahuan tidak baik yang melakukan tindakan sebanyak 4 orang $(44,4 \%)$. Sedangkan responden yang pengetahuan baik dan tidak melakukan tindakan sebanyak 4 orang $(11,4 \%)$, dan responden yang pengetahuan baik dan melakukan tindakan sebanyak 31 orang $(88,6 \%)$. Setelah diuji statistik dan pengolahan data yang menggunakan perhitungan chi square dengan bantuan SPSS Persion 21 for windows, diperoleh nilai $P=0,010$ maka dapat disimpulkan ada hubungan yang signifikan antara pengetahuan dengan tindakan perawat dalam pengelolaan sampah medis.

\section{PEMBAHASAN}

Berdasarkan hasil uji hipotesis disimpulkan bahwa ada hubungan antara tingkat pengetahuan dengan tindakan perawat dalam pengelolaan sampah medis di RSU Sembiring Deli tua. Semakin tinggi pengetahuan perawat tentang pengelolaan sampah medis, maka semakin baik pula tindakan perawat dalam pengelolaan sampah medis tersebut. hubungan yang searah ini dapat dilihat dari hasil analisis uji statistik yang menunjukkan korelasi yang positif. Hasil penelitian juga memperlihatkan data masih terdapat 9 responden $(20,5 \%)$ dengan pengetahuan yang tidak baik. Kurangnya pengetahuan responde tersebut jika dikaji masih kurang benar dalam menjawab pertanyaan dalam pengelolaan sampah medis, seperti pengelolaan sampah spuit habis pakai. $\mathrm{Hal}$ ini dimungkinkan responden tidak mengetahui resiko yang terjadi dengan adanya infeksi silang.

$$
\text { Penelitian Maulana }
$$

menunjukkan kebutuhan akan program pelatihan untuk berbagai tingkat staf dirumah sakit dari administrator, manajer, dokter, perawat sampai petugas penanganan dan pemeliharaan sampah medis di rumah sakit. Ali (2008) mengemukakan dalam rangka mewujudkan dan memenuhi standar kualitas kesehatan pengelolaan sampah medis di fasilitas kesehatan, petugas pengangkut sampah medis termasuk perawat harus dilatih untuk melaksanakan tugas secara akurat dan aman. Di Thailand, meskipun rumah sakit tidak memiliki program reguler pelatihan untuk staf, maupun staf baruu diberi orientasi menyeluruh dan kuliah tentang keselamatan kerja di tempat kerja dan berhubungan dengan manajemen limbah medis. Penelitian Ojo - Omoniyi (2015) menyebutkan pengelolaan sampah medis cairan harus dikelola secara benar mengingat sampah cair medis dapat mikroorganisme berkembangbiak.

Hasil pengetahuan responden yang tidak baik dalam pengelolaan sampah medis dapat dipengaruhi oleh banyak stimulus. Kurangnya pengetahuan perawat dalam pengelolaan sampah memilah sampah sebelum dimasukkan kedalam sampah sesuai jenis kantong sampah berpengaruh pada tindakan perawat dalam pengelolaan sampah medis. Parsinahingsih (2008) mengenai gambaran pelaksanaan kewaspadaan standart di RSUD Dr. Moewardi bahwa masih terdapat perawat yang kurang baik dalam pelaksanaan kewaspadaan standart seperti pasien safety maupun penerapan membuang sampah medis saat melakukan asuhan keperawatan kepada pasien. 
Risiko timbul akibat dari tindakan yang masih tidak baik, dapat mengakibatkan berkembang biaknya mikoorganisme dari pengolahan limbah yang dilakukan sebelum dibuangnya limbah medis. Kondisi lingkungan kerja dapat mempengaruhi pengetahuan yang akhirnya mempengaruhi tindakan responden penerapan kewaspadaan terhadap pengelolaan limbah sampah medis, ketersediaan fasilitas kerja dan fasilitas untuk memperoleh informasi tentang meliputi ketersediaan buku referensi, kemudian akses-akses penelitian. Menurut Chatherine (2010) peran lembaga pendidikan keperawatan untuk mengajarkan prinsip-prinsip stantard precautionyang didalamnya terdapat prinsip pengelolaan limbah infeksius, dalam hal ini diklat keperawatan merupakan lembaga pendidikan keperawatan informal dilingkungan rumah sakit saat ini belum memiliki perpustakaan yang memadai dalam penyediaan buku terkait kewaspadaan standart dan belum adanya jadwak pelatihan penanganan infeksi nosokomial secara berkala dar pihak rumah sakit.

Pernyataan tersebut sesuai dengan penelitian bahwa masih ada 9 responden $(20,5 \%)$ tidak melakukan tindakan. Hal ini dapat dipengaruhi oleh faktor bahwa responden belum pernah mengikuti pelatihan kewaspadaan standart yang didalamnya terdapat cara pengelolaan sampah medis rumah sakit secara baik dan benar. Sebagai tenaga kesehata yang 24 jam langsung berinteraksi dengan pasien, perawat harus memiliki pengetahuan yang baik dalam menerapkan kedisiplinan dalam melakukan pengelolaan sampah medis dibutuhkan pengetahuan yang baik, serta melakukan tindakan pengelolaan sampah medis agar dapat mengurangi risiko terpapar infeksi pada diri sendiri, pasien dan masyarakat dari pengelolaan sampah medis tersebut.
Hasil penelitian ini juga diketahui bahwa pengetahuan responden yang baik ternyata tidak selalu diikuti oleh tindakan yang baik. Hal ini kurang sesuai dengan pernyataan Azwar (2006) bahwa tindakan seseorang dapat dipengaruhi oleh faktor penguat (reinforcing factors) seperti faktor sikap dan perilaku tokoh, dalam hal ini kepala ruang dalam memberikan informasi pentingnya pengelolaan sampah medis ditiap ruangan dengan benar. Terdapat faktor lingkungan kerja seperti masih timpangnya rasio antara jumlah perawat yang ada dengan jumlah pasien di area rumah sakit. Kondisi ini mengakibatkan perawat harus dituntut untuk dapat melaksakan tugas asuhan keperawatan kepada seluruh pasien. Hasil penelitian ini sejalan dengan skripsi Lilis Nurharyanti (2016), bahwa terdapat hubungan antara tingkat pengetahuan dengan perilaku perawat dalam pengelolaan sampah di ruang rawat inap RSUD Sukoharjo.

\section{KESIMPULAN}

Berdasarkan hasil penelitian tentang Hubungan Tingkat Pengetahuan Dengan Tindakan Perawat Dalam Pengelolaan Sampah Medis Di RSU Sembiring Deli tua, kesimpulan dalam penelitian ini adalah : Berdasarkan hasil penelitian di dapat hasil responden paling banyak dengan kategori pengetahuan baik sebanyak 35 orang $(79,5 \%)$, dan kategori pengetahuan tidak baik sebanyak 9 orang $(20,5 \%)$. Sedangkan hasil penelitian responden paling banyak dengan kategori tindakan yaitu responden melakukan tindakan sebanyak 35 orang $(79,5 \%)$, dan kategori tidak melakukan sebanyak 9 orang $(20,5 \%)$. Setelah diuji dengan uji chi square dapat diketahui bahwa nilai signifikansi value $=0,010(P<a 0,05)$ yang menunjukkan bahwa ada hubungan antara pengetahuan dengan tindakan perawat dalam pengelolaan 
sampah medis di RSU Sembiring Deli tua.

Berdasarkan hasil penelitian dan pembahasan dapat kesimpulan sebagai berikut :

a. Ada hubungan yang signifikan antara tingkat pengetahuan dengan tindakan perawat dalam pengelolaan sampah medis di RSU Sembiring Deli tua dengan nilai $\mathrm{p}=$ 0,010 .

\section{DAFTAR PUSTAKA}

Asmadi. (2013). Pengelolaan Limbah Medis Rumah Sakit, Yogyakarta : Gosyen Publishing.

Nurharyanti. (2016). Hubungan Antara Tingkat Pengetahuan Dengan Perilaku Perawat Dalam Pengelolaan Sampah Medis Di Ruang Rawat Inap Rumah Sakit Sukoharjo Tahun 2016. Universitas Muhammadiyah Surakarta : Jurnal Kesehatan Masyarakat.

Chandra, B. (2018). Pengantar Kesehatan Lingkungan. Jakarta : EGC.

Notoatmodjo, S. (2012). Promosi Kesehatan Dan Perilaku Kesehatan. Jakarta : Rineka Cipta.

Notoatmodjo, S. (2017). Metodologi Penelitian Kesehatan. Jakarta : Rineka Cipta.

Chaniago.(2013).https://ansharchaniag o.wordpress.com/2013/02/24 Pengelolaan-sampahlimbahrumah-sakit-danpermasalahannya.

KLHK. (2018). Limbah Medis Di Indonesia capai 242TonPerhari.https://www.r epublika.co.id/berita/nasional /pobox1d384. klhk. Limbahmedis-di-indonesia-capai242-ton-perhari : Padang.
Tanjung, J. (2017). Limbah Medis Ditelantarkan

RSUDBatubara.https://sumut pos.co/2017/11/29/limbahmedis-diterlantarkan-rsudbatubara. Sumatera Utara.

Tumanggor, A. (2018). Inilah Trobosan Kementerian Lingkungan Hidup dan Kehutanan (KLHK) Atasi Persoalan LimbahMedis.http://medan.tri bunnews.com/2018/04/13.co m.

Damara,L.(2012).http://levinadamara. blogspot.com/2012/08/ciriciri-sikap.html?m=1. Sumber : www.edwias.com

Azwar. (2009). Sikap Manusia Teori dan Pengukurannya.Yogyakarta : Pustaka Pelajar

Fahriadi. (2010). Limbah Medis dan Kesehatan.

https://www.scribd.com/ doc/33519413/Limbah-MedisDan-Kesehatan.

Lutfiah,E.(2014).

https://evalutfiah.blogspot.co $\underline{m}$ /2014/12/bab4. html?m=1.

Hidayat, A.

https://www.statistikian.com /2017/12/hitung-rumusslovin-sampel.html

Wungo, N, M. (2013).Hubungan Antara Pengetahuan dan Sikap Petugas Sanitasi dengan Praktik Pengelolaan Sampah Medis di RSUD Kabupaten Kebumen tahun 2013. Jurnal Kesehatan.

Solikhah, S. (2012). Hubungan Pengetahuan dan Sikap Dengan Perilaku Dalam Membuang Sampah Medis di Rumah Sakit PKU Muhammadiyah Yogyakarta. Jurnal Kesehatan Masyarakat. ISSN 1976-0576. 
Jasmawati. (2012). Hubungan

Pengetahuan, Sikap, dan Ketersediaan Fasilitas dengan Praktik Petugas pengumpul Limbah Medis di RSUD Abdul Wahab Sjahranie Samarinda. Jurnal Kesehatan Masyarakat Universitas Hasanuddin Makassar.

Maulana, M. (2015). Manajemen Pengelolaan Limbah padat Rumah Sakit Jogja. Jurnal Kesehatan Masyarakat 